Notre Dame Law School

NDLScholarship

Natural Law Forum

$1-1-1957$

\title{
A Prospectus for a Symbolist Jurisprudence
}

Robert E. Rodes

Follow this and additional works at: http://scholarship.law.nd.edu/nd_naturallaw_forum

Part of the Law Commons

\section{Recommended Citation}

Rodes, Robert E., "A Prospectus for a Symbolist Jurisprudence" (1957). Natural Law Forum. Paper 20.

http://scholarship.law.nd.edu/nd_naturallaw_forum/20

This Article is brought to you for free and open access by NDLScholarship. It has been accepted for inclusion in Natural Law Forum by an authorized administrator of NDLScholarship. For more information, please contact lawdr@nd.edu. 


\section{A PROSPECTUS FOR A SYMBOLIST}

\section{JURISPRUDENCE*}

Robert E. Rodes, Jr.

Symbolism, so influential as a poetic movement, seems to be more a view of the human condition to which poetry is addressed than of poetry itself, and therefore to have possibilities for metaphysical and jurisprudential extrapolation. The symbolist position seems to be that events-things or happenings - can be used as symbols without any accompanying statement of what they symbolize. This is to say that events have meanings that the poet can bring out merely through his presentation of the events themselves. Thus, lines like

Shall I say, I have gone at dusk through narrow streets

And watched the smoke that rises from the pipes

Of lonely men in shirt-sleeves, leaning out of windows? . . .

I should have been a pair of ragged claws

Scuttling across the floors of silent seas. ${ }^{1}$

do not, like romantic poetry, present the event in conjunction with an emotional response to it:

My heart leaps up when I behold

A rainbow in the sky ...2

nor do they, like allegory, simile, or metaphor, in presenting the event, state the meaning given it by the author:

The quality of mercy is not strain'd,

It droppeth as the gentle rain from heaven . . . 3

The road was a ribbon of moonlight over the purple moor . ..4

Nel mezzo del camin di nostra vita

mi ritrovai, per una selva oscura

chè la diritta via era smarrita. 5

- The writer is indebted to Mr. Joseph J. Sikora, Department of Philosophy, University of Notre Dame, for a number of helpful suggestions.

1. Eliot, The Love Song of J. Alfred Prufrock, lines 70-74.

2. Wordsworth, "My Heart Leaps Up . . ." The "event" here is the rainbow.

3. Shakespeare, The Mrrchant of Venige, IV. i. 184-5. Here, the event "rain" is used by way of commentary on "mercy."

4. Noyes, The Highwayman, line 3.

5. Dante, Inferno, 1, 1-3. The event here is the highway. "Nostra vita," the meaning, serves as a label. 
Instead, they present to the reader events which the author supposes to carry with them the requisite meaning, the requisite response. The effectiveness of such poetry argues persuasively that authors who use the technique are right in supposing the events they set forth to have meanings that may be discerned in the events themselves without independent statement by the author.

This seems to be a presupposition not merely of symbolist poetry, but of all poetry, for even those poets who feel called upon to state the meaning of the events they refer to have never been free to be entirely subjective in assigning those meanings. Leaving to one side the purely visual metaphor from The Highwayman, which is obviously limited by the objectivity of the eye, let us consider the following emendations of the cited passages:

My heart leaps up when I behold

A puddle on the ground ...

The quality of mercy is not strain'd,

It flasheth as the lightning bolt from heaven . . .

Nel mezzo del bagno di nostra vita

mi ritrovai per una acqua oscura

chè lo vero sapone era smarrito . . .

That these lack the poetic quality of their exemplars can scarcely be denied. It would seem, then, that we must describe the poetic insight as an aptitude for discerning meanings in events, rather than for putting them there.

Since symbolism as thus set forth is a derivative of poetic experience its consequences are limited by the scope of the validity to be accorded such experience. It is this writer's conviction that such experience can be accorded universal validity. Using the poet's terminology we may state this conviction thus:

The human condition is common to all mankind. This statement is formally a tautology because the poet has prejudged it in adopting his terminology. But what he means by the "human condition" is not "that which is common to all mankind," but "the object of poetic insight," the thing he shows us momentarily on those rare occasions when he makes us cry. To say that this is common to mankind is to say that there is something deep and shared on the basis of which every man can appeal in some way to every other ${ }^{6}$ _cor ad cor loquitur. I have, in other words, not only an experience of what it is to be myself, but also an experience of what it is to be a man-an experience of the human condition. Thus,

6. Cf. Maritain, On Knowledge through Connaturality, in The RAnge of Reason (New York, Scribner's, 1952). 
one man can draw from his experience generalizations that will be applicable to other men, and that he can hope will be persuasive to them. This is not to say that A's experience of what it is to be a man is more valid than B's, but only that it is as valid for B as it is for A.

The acceptance or rejection of the foregoing principle of a common human condition is the most profound of philosophical choices; no less than the whole of a man's experience goes into making it. One can no more argue with a person who decides for rejection than one can explain love poetry to a child. One can only say that there is more to life than such a person has supposed.

The epistemological consequences of the foregoing would seem to be that certain cognitions are appropriate to the human mind as such, and that whatever can be the object of human experience can be the object of such a cognition. The act of cognition in this framework becomes a sharing of human experience, a communion with other men. ${ }^{7}$ This position is not identifiable with a particular epistemological system, although it is consistent with some and inconsistent with others.

Making a rough classification of epistemological systems, as they are germane to our purposes, under the three heads of realism, nominalism, and idealism, we can see that realism is consistent with the position here taken. To be sure, the realist tends to talk of cognition of things as they are, rather than of events as they present themselves to human experience. But one can hardly have the first without the second. If we admit that all the objects of experience are such as to elicit certain cognitions of the human mind, we can scarcely deny that certain cognitions are appropriate to the mind, or that all the objects of experience can be the objects of such cognitions.

We can further see that nominalism is inconsistent with the position here taken, because it necessarily denies the common human condition. It sets up the empirical fact of disagreement as the rock on which all cognition must founder, and conceives the task of philosophy to be one of facilitating cooperative behavior where goals are coincidentally common. Since the common human condition forms a basis for the experiential resolution of disagreements in terms of who is right, it can only be through denying it that the nominalist arrives at the necessity of finding himself agreed with before he will proceed.

Idealism presents a more complex problem in this regard. Basically, idealism is any position which attributes to the observer something realism

7. Cf. Tate, The Man of Letters in the Modern World in the collection of the same name (New York, Meridian Books, 1955). 
attributes to the object. As such, it seems to be neutral with respect to the epistemological position here adopted. Most idealist schools, however, while retaining the conception of the common human condition, tend by the nature of the epistemological inquiries they undertake to narrow its scope in some way. Insofar as their results are consistent with the possibility of cognition as here understood, their jurisprudential consequences will be akin to those of realism. Insofar as their results are restrictive of this possibility of cognition, they will be insufficient to form the basis of a complete system of jurisprudence unless they draw on the jurisprudential devices employed by nominalism.

Since there seems to be no terminology common to idealism and realism whereby elements common to both can be referred to, the terminology of realism will be used throughout this essay to designate principles fully consistent with the epistemological position here adopted. Thus, the appropriateness of a cognition to the human being as such will be designated in this essay as "real," with the understanding that this usage is not intended to foreclose the question of whether that appropriateness is in the object or in the human being.

It seems, then, that the validity of generalizations on experience is a consequence of the common human condition, and requires an epistemology that can, with the qualifications just stated, be set forth in realist terms. The experiential principle of symbolism can now be stated within this framework, and will take the following form:

Events have real meanings.

What is meant by "real" has just been stated. Some expansion on the use of the other two terms may, however, be in order. As here used:

1. An "event" is whatever can be the object of human experience. The term is advisedly used univocally of both natural and man-made phenomena in order that the statement may be a true metaphysical statement, rather than one confined in its application to the framework of a given cultural system. It should be noted that a norm, as such, is not an event as here understood. The existence or nonexistence, validity or invalidity, of a norm can all be the objects of experience, but the norm itself cannot.

2. The "meaning" of an event is a perceptible but indefinable relation between the event and something else. The "something else" may be itself an event, or may be an event only in a qualified sense, as capable of being the object of experience only through events of which it is the "meaning." For ease of expression, "A means B," "A is a symbol of $B$," " $A$ symbolizes $B$," and " $B$ is the meaning of $A$ " will be used 
interchangeably. The relation between symbol and meaning will be called a "symbolic" relation, and a complex of such relations will be called a "symbolism." The reason why the symbolic relation is indefinable is that the perception of it is intuitive or experiential. Thus, the existence of the relation cannot be derived from perceived indicia, and no such indicia can be stated. The nature of the relation will perhaps be clarified in the course of this essay.

Having defined as well as is practicable the principle of symbolism, we may consider its position in a jurisprudential system. But before proceeding to this, some consideration should be given to a principle that may have jurisprudential consequences similar in certain respects to those of the one here adopted. That principle would be this:

Man-made events have meanings that inhere in the cultural milieu in which they occur.

This, it will be noted, is a partial affirmance of the principle just stated. It will serve to evaluate law in terms of the culture in which it subsists, but it will not serve to evaluate that culture, and therefore will not serve as an ultimate evaluative criterion for law. It is this writer's conviction that such a principle will furnish neither an adequate system of jurisprudence nor the most nearly adequate system of jurisprudence it is possible to have. Nevertheless, much, though by no means all, of what will be said below can be as validly derived from this principle as from that first stated. One who can accept only this second principle will have to reject a certain amount of what is said below, and qualify a good deal more; what must be rejected or qualified should be sufficiently clear to make explicit indication unnecessary. It seems likely that what remains may be of some use to him.

Turning, then, to the jurisprudential consequences of the principle that events have real meanings, it is apparent that if this writer is right in believing that an adequate system of jurisprudence must furnish an ultimate evaluative criterion for law, this principle will not by itself form the basis for an adequate system of jurisprudence. The questions that have always been asked about the evaluation of law remain unanswered. Thus, the principle must be offered as additional to, not as a substitute for, traditional metaphysical formulations that lead to principles of evaluation.

The task traditional metaphysics sets itself seems in general to be a consideration of the structure of reality, that is, of the relations between events whereby they may be systematically described and fitted into a harmonious whole. Applying the epistemological and terminological system developed above to our experience of the appropriateness of certain structur- 
ings of reality, we can state the following principle of structural metaphysics:

Reality has a real structure.

Both the meaning of this principle and the reason why this writer adopts it should be apparent from what has gone before.

One who accepts a principle of symbolism confined in its application to a given culture will perhaps accept a similar modification of the structural principle just stated:

Man-made events have a structure dictated by the culture in which

they occur.

One who accepts such a principle can be invited, with the qualifications already stated, to proceed.

The realist system that has had the most influence on jurisprudence is that of scholasticism, with its particular version of the "natural law." Since the methodology of that system is basically one of generalization of experience, it follows from what has been said here that that system is methodologically valid. On the other hand, the methodology makes it possible to correct any of the particular formulations of the system on experiential grounds. Symbolism provides just such an experiential corrective. Since the scholastic system is entirely concerned with structure, symbolism will for the most part show it to be inadequate rather than false. Specifically, it may provide the practical applications for disciplines other than philosophy which scholasticism has so long lacked, together with a way of integrating into structural metaphysics the discoveries of modern psychiatry, which seems rapidly to be approaching a principle of symbolism like that here stated.

The inadequacies for which symbolism can provide seem to be in the general area of motivation. The scholastic tends in this area to give a definition in lieu of an explanation. This is particularly apparent in the case of love, which he is apt to define in such a way as to shortcut the process of externalization that poetic experience discerns as a basic and imperfectly satisfied necessity of the human condition. Reality fills us with a vast and inexpressible spiritual longing (the same, indeed, that convinced Plato that heaven, not earth, is our home), which, by the exercise of symbolic perception, we particularize as best we can in terms of some more or less obtainable material reality. Thus Meredith's:

... she is what my heart first awaking

Whispered the world was. ${ }^{8}$. .

When Aristotle, or St. Thomas, ${ }^{9}$ says that love is the desire for someone's

8. Love in the Valley, stanza 6, lines 5-6.

9. E.g., Summa Theologiae I-II, q. 26 art. 11. 
good-the desire that an event take place-he makes the end result of such a process of particularization identical with what set the process in motion, thereby eliminating the process itself. The consequences for his system are nil as long as the system avoids concerning itself with the case in which the process is not successfully achieved. That the system does avoid so concerning itself is a matter of serious consequence, as will be seen. ${ }^{10}$

It is the purpose of the present essay to explore the jurisprudential consequences of the symbolic principle together with the consequences of integrating that principle into the jurisprudential derivative of the structural metaphysic: the natural law. The plan of attack will be to classify various intellectual movements with their jurisprudential consequences in accordance with their answers to the two questions of whether events have real meanings and whether reality has a real structure, and then to attempt the development of an experientially valid jurisprudential system consistent with answering both questions in the affirmative.

1. Reality has no real structure, and events do not have real meanings. - This is the philosophical consequence of rejecting the principle of the common human condition. Since no common element inheres in the human condition, the judgment my neighbor makes on his experience can in no way be evaluated in terms of the judgment $I$ make on mine. This is the foundation of the metaphysical doctrine of nominalism, and of its derivatives, the scientific doctrine of a random universe, and the semantic doctrine ${ }^{11}$ that distinguishes between reports (of sense data, which proponents of the doctrine admit to be verifiable by common standards) and judgments (not exclusively based on sense data, and therefore subjective). Since the individual is at the roots of his existence isolated from his fellows, constructs upon empirically observed potentialities for agreement in surface matters become all-important. The task of the intellectual is one of constructing an artificial order in the midst of a natural chaos.

This is the task jurists of this persuasion set themselves. Taking the desire of each person as an irreducible datum, ${ }^{12}$ they address themselves to

10. See p. 99, infra.

11. E.g., Hayakawa, Language in Action 40-54 (New York, 1939).

12. By "irreducible datum" is meant a datum that cannot be explained in terms of other data. "Evaluation," as the term will be used in this essay, is impossible without explanation, since unless there is a reason why $A$ desires $X$ or $Y$, we cannot say whether $A$ has a better reason for desiring $\mathrm{Y}$ than for desiring $\mathrm{X}$. Note that this leaves room for evaluating the 
the establishment of legal institutions that will insure the peaceable satisfaction of as many such desires as possible. Their ultimate purpose in establishing such institutions seems to be an orderly society. If asked why they seek to establish an orderly society rather than a chaotic one, they will answer that they prefer it, and that in keeping with their principles their preferences are irreducible data, for which no explanation is either possible or necessary.

Historically, this philosophical position has supported two major schools of jurisprudence. The individualist school sought to extend into the material world the moral isolation of the individual by developing the traditional legal institutions of property and contract into a system for drawing boundaries. The whole force of the law was grouped around these two institutions, and so structured as to provide an objective determination of what segment of matter was subject to what man's desire. The insistence on the objective and the analytical preserved the system from the danger of relapsing from its boundary-drawing function into the impermissible realm of evaluating desires. Hence the epithet, "mechanical jurisprudence."

The alternative to extending the moral isolation of the individual into the world of matter seems to be that of emphasizing in the world of matter any observed concurrences of human desires. This calls for a careful search to discover such concurrences and develop appropriate mechanisms for giving them effect. The utility of the ballot box as a simple method of determining such concurrences led to theories of unrestricted democracy. The more sophisticated empirics of the social sciences led to sociological jurisprudence. In either case, the effort was to establish machinery that would accomplish the desires of as many people as possible. The law's task, in other words, was not to fragmentize matter for subjection to conflicting desires, but to coordinate it for cooperative achievement of the more widespread desires. But the common denominator between these systems and individualism was the irreducibility of human desire as a datum.

In recent years, we have renewed our acquaintance with the potentialities for depravity in the human heart. Life in the modern world is forcing more and more of us to admit that human desires must be evaluated. It seems clear

fulfillment of a given desire. "A desires that $\mathrm{X}$ event take place" may itself have no explanation, but it can be put forward as a reason why $\mathrm{X}$ event should take place, and we can consider whether it is better or worse than the reasons why $X$ event should not take place. Note also that treating desires as irreducible data does not exclude reducing one desire to another desire of the same person: "A desires that $X$ event take place because he desires that $\mathrm{Y}$ event take place, and believes that $\mathrm{X}$ event will be conducive to $\mathrm{Y}$ event." It is then possible to make the evaluation: " $X$ event will not be conducive to $Y$ event; therefore, A ought not to desire that $X$ event take place." This is typical of the things with which nominalist philosophers are concerned. 
that evaluation requires reduction. ${ }^{13}$ At the same time, psychiatrists since Freud have generally undertaken the reduction of desires, some with more success than others, but collectively with a promise of success that can no longer be ignored. Social scientists are beginning to bear them out with reductions of their own. These considerations, by undermining the principle of the irreducibility of desire, are making the nonrealist position a jurisprudential blind alley. If the evaluation of a man's desires is to be accomplished without reducing the man himself to a means to some extrinsic end, it must be on the basis of some common experience of what it is to be a man. Scholars raised in the tradition of nominalist jurisprudence are beginning, therefore, either to defect from the whole tradition, or to lead the tradition itself along a path toward the commonness of the human condition, which is the first premise of what is here called realism.

2. Reality has a real structure, but events do not have real meanings. -This position seems to be the consequence of admitting the fundamental tenet of the common human condition, but denying or failing to take into account the fact that the common condition contains an insight whereby events have meanings. Of the philosophical positions that have given rise to influential jurisprudential schools in recent centuries, three seem to fall at least to some extent within this category. These are scholasticism, rationalism, and economic determinism. Of these, only scholasticism has presented as the common element in the human condition something that continues to commend itself to substantial numbers of scholars as a selfsufficient approach to the whole of experience.

Rationalism, the source of the a priori version of the natural law that modern scholastics have struggled so valiantly to disown, finds as the common element in the human condition reason, a methodology. Thus, the rationalist bases his system of jurisprudence on some proposition that he supposes to be a dictate of reason. The proposition thus favored has often enough turned out to be the irreducibility of human desires so that it is not at all easy to unscramble the rationalists from the nominalists in nineteenth-century jurisprudence. Both must share the blame for individualism.

More recent commentators are just about unanimous in insisting that social principles do not flow from pure reason, and that the rationalist writers are really reflecting their emotional biases or the mores of their society. The rationalist generally tends to retreat under this attack to whatever metaphysical ground will support his particular jurisprudential presupposition. This usually turns out to be nominalism.

13. See note 12 , supra. 
Economic determinism, attributing to mankind a common motivation, does not purport to offer a self-sufficient guide to the whole of experience, and therefore cannot be regarded as attributing a real structure to more than certain aspects of reality. But once the advocate of economic determinism overcomes the formidable experiential and logical hurdles presented by his basic doctrine, he has no difficulty in deriving from it a full and objective system of jurisprudence, so long as he confines his appeals for support to those who stand to benefit economically from the system he proposes. ${ }^{14}$

The general grounds, logical and experiential, for rejecting the systems of rationalism and economic determinism are well known. All that need be added here is that both of these systems seem to regard their conceptions of the common element in the human condition as exclusive, or at least as exclusive of the poetic insight that is the presupposition of the present inquiry. The poetic insight is other than rational, and leads to motivations other than economic. To accept the common human condition as it has been stated in this essay is to reject these two conceptions of it.

Turning, then, to the remaining system, that of scholasticism, we find it deserving of closer attention. The common element to the scholastic is a perception. Man sees events as connected with one another-sees a real structure in reality. This is in no way inconsistent with seeing real meanings in events. That scholastic philosophy has overlooked the element of meaning seems to be no more than the product of a series of unhappy coincidences.

The medieval scholastic lived in a society rich in symbol. Within it, the Christian revelation with its sacramental and philosophical concomitants was in conflict with various classical and Islamic notions for the hearts and minds of men. ${ }^{15}$ The scholastic philosopher won for Christianity a victory in the realm of minds that was to go unchallenged for centuries, but somehow in the process Christianity lost much of its hold over men's hearts. The scholastic did not deny the existence of meaning in events, but he failed to set himself the task of symbolic evaluation that might have put more life in his philosophy. There is a sacramentality in nature that powerfully supports the sacramental system of revealed theology, and this the scholastic let slip from his grasp. We find in the later Middle Ages a gathering force

14. This he generally purports to do. Thus, the Communist jurist evaluates law by the demands of his "socialist state" but does not expect anyone but the proletarians to approve of what he is doing. See Vyshinsky, The LaW of the Soviet State (New York, 1948). The laissez-faire capitalist does something rather similar when he appeals to the mass of the people for support either in terms of the possibility of the poor man becoming rich or in terms of the eventual benefit to the whole community from the economic expansion motivated by the availability of profits.

15. This conflict is described in Denomy, The Heresy of Courtly Love (New York, McMullen, 1947). 
of advocates of conduct symbolic of temporal things-love, fruition, life-force, masculinity, honor, and the like-despite the admitted nonconformity of such conduct with the structure of reality as discerned by the philosophers. The period we call the Renaissance is one in which society came to be wholly dominated by these secular symbols.

The reaction was to purge away all symbolism at once. The Protestant reformers insisted on cutting through the corruption of the times a direct path for the human soul to God. The sacraments, images, and liturgy of the Church, and all forms of frivolity in secular life, went by the board together. Henceforth, church and society alike were to be grimly onedimensional, grimly purposive. ${ }^{16}$

The Church in the midst of the general cataclysm anchored herself on the structural philosophy that was her chief legacy from the Middle Ages. By the mystery of her constitution, she could teach no other doctrine than she had always taught concerning sacraments, images, the symbolic relation between faith and works, and the various forms of mediation between God and man. But the philosophical foundation was badly undercut by the disappearance of the medieval society with its affinity for sacramentality in nature, its symbolic organization. The Catholic philosopher met the newfound discrepancy between sacramental theology and merely structural philosophy by hardening the distinction between the natural and the supernatural. His theology lived in the new purposive society as a stranger, intellectually impregnable, but stripped as much as man can strip it of its power to move the heart.

Neither the decline of Protestant ethics nor the revival of liturgical piety has led the scholastic philosopher, generally speaking, to turn his attention to the meanings of events. $\mathrm{He}$ is like a man who sees a picture of the famous flag-raising on Iwo Jima and observes of it that it is in the nature of flags to be put up on poles.

In the area of jurisprudence, the modern scholastic philosophers have been highly articulate with their theories of the natural law. It should not be necessary to set forth more of their teaching than is necessary to show the difficulties introduced into it by the defect here under considerationthe failure to apprehend that events have real meanings. The teaching involved seems to be that there is in the human condition a teleology-a

16. What is meant here by "purposive" is tending to evaluate all things in terms of their efficacy in achieving some purpose assigned them. So to characterize society as it has existed since the Middle Ages is not to take issue with those who have complained of it that it is excessively preoccupied with means to the exclusion of ends. Quite the opposite: to say that a society evaluates all things in terms of ends is to say that it regards all things as means. 
position in the structure of reality to which a man must conform if he is to fulfill the most basic demand of his nature. This teleology and the means of conforming to it collectively constitute the "natural law." 17 This view, unlike those that deny real structure in reality, does not treat human desires as irreducible data, but evaluates them against the teleology it discerns for mankind.

But the evaluation is teleological and not symbolic. Meanwhile, the psychiatrists and the social scientists are examining the motivations for human conduct, and discovering behind teleologically objectionable conduct powerful symbolic motivations. 18 These the natural law philosopher disdains, continuing to insist on his teleological considerations without regard to the symbolism that motivates violating them. The follower of the philosophical system is thus presented with a terrible clash between the dictates of heart and head. But the discrepancy between symbolic conduct and teleological conduct is obviously spurious. If reality is indeed reality, what is bad teleology can scarcely be good symbolism. Christian and poetic traditions alike present ample material for symbolic evaluation as well as teleological evaluation, and tending to the same result. The Catholic natural law philosopher is greatly to blame for failing to draw on it.

3. Events have real meanings, but reality has no real structure.-This is the position of the savage, for whom the sky is full of unconnected signs and portents. It seems also to be the position of the existentialist, and of a good many authors in the modern tradition. Hemingway, Faulkner, and Mlle. Sagan, with a host of others, seem to treat every gesture as pregnant with meaning, and yet to see no systematic connection among the things meant. Like anyone with true poetic insight, they have been unable to escape their empathetic response to the human condition, despite their unwillingness to accept any system of structure. Others, like Baudelaire, and perhaps Gide, seem to have tended more to the medieval pattern discussed above of accepting a structural system intellectually, but pursuing in practice

17. The view under consideration seems to distinguish inadequately if at all between natural law and morality. See Leclercq, Suggestions for Clarifying Natural Law, 2 NATURAL LAW FORUM 64 (1957). This fact is peripherally relevant to the present inquiry, and will be dealt with peripherally later on. "Natural law" will be used in this essay as it is used by these philosophers. An amendment of the terminology is obviously in order, but this does not seem to be the place to undertake it. Since the principles of jurisprudence proposed in this essay are offered as emanating from what might be called human nature, there is a sense in which they could be called principles of "natural law." But it would take an involved structure of subscripts to make this sense clear.

18. For example, "status" and "security," as used in these disciplines, cannot properly be said to be material states producible in the real world. They can only be symbolized in material things. 
meaningful conduct violative of the structural system. Two scholars, Huizinga ${ }^{19}$ and Veblen, ${ }^{20}$ have pursued extremely important researches into patterns of conduct that might be regarded as symbolic, taking in the process positions that seem to admit of a structure in reality, but not one that will serve to evaluate the conduct they describe. In other words, they admit the possibility of purposive conduct, but conceive it to be different in kind from the symbolic conduct with which they deal. ${ }^{21}$ Thus, of those maintaining the position shown here, a number would add important qualifications. All, however, seem to admit that events have real meanings, and either to deny or to leave out of account the existence of real structure in reality.

If we were to consider only the existentialists and the modern authors, we might be led to suppose that this position is without jurisprudential manifestations. It is entirely possible, however, to find particular kinds of patterned conduct meaningful without admitting a general structure in reality; other ages have furnished examples. Thus, the jurisprudence of the Court of Love at Poitiers would seem to be premised on the view that "A loves B" is an irreducible datum, since love must by its very nature be entirely unbound, but that whether a given event is symbolic of that datum is an objective question appropriate for judicial determination. Thus, also, the French classical dramatist manipulates a set of irreducible emotions objectively symbolized, and achieves his plot effects by tearing his characters apart in a clash of symbolisms. A typical plot of this school may be analyzed in the following paradigm: " 'A loves $B$ ' is an irreducible datum objectively symbolized by $\mathrm{X}$. 'A values his honor' is an irreducible datum objectively symbolized by not-X. What shall A do?"'22

Among general theories of law, we find that two seem to fall within the position that admits meaning but denies structure. First, the historical school teaches that law is a spontaneous emanation from the ethos of a people-the Volksgeist. But law does not constitute the Volksgeist for this school, nor is the Volksgeist defined as a motivation toward a particular legal system. The school would seem to teach, then, that the way the legal system emanates from the Volksgeist is by symbolizing it-that law is

19. Homo Ludens (London, Routledge \& K. Paul, 1949).

20. The Thzory of the Leisure Class (Modern Library ed., 1934).

21. Thus, to Huizinga, some activities are "play," others are not. To Veblen, some activities are "conspicuous leisure" and the like, others are productive.

22. This pattern appears twice, for example, in Corneille's Le Cid: (1) A is Chimène; $B$ is Rodrigue; $X$ is Chimene's marrying Rodrigue. Hatred for the man who killed her father becomes not-X when Rodrigue kills her father. (2) A is Rodrigue; B is Chimène; $X$ is doing nothing to make Chimène unhappy. Avenging insults offered to his father becomes not-X when her father insults his father. 
an event, that that event has a real meaning, and that that meaning is the Volksgeist. The Nazi theoreticians seem to have drawn on this school, and thereby to have greatly discredited it. The trouble is that there is in every Volk, as there is in every man, a mixture of good and evil. Recent history has made this obvious. We feel now more than ever a need for evaluative principles, and the Volksgeist will not help us.

The second of these theories, and one that cuts a good deal deeper than the Volksgeist theory, is that of Edmond Cahn. Professor Cahn discerns a "sense of injustice" which is aroused by certain affronts to the human personality. This sense is empathetic (hence not responsive to teleological observations) and universal (hence, under the epistemological principles stated above, capable of producing insights into reality.) That the considerations that move it are symbolic is quite clear in some of the examples, less so in others. ${ }^{23}$ Basically, however, the appeal to empathy seems to be an appeal to symbolism. It is not the infliction of pain as such that arouses the sense of injustice, but its infliction in a manner which symbolizes the antithesis of that empathetic bond that unites mankind. ${ }^{24}$

Cahn's views are encouraging ones to find gaining currency at this time. But this writer, like others of the same persuasion, cannot grant him that his "sense of injustice" is exclusively empathetic. Two qualifications must be insisted on. First, the existence and manifestations of that "sense" can be correlated with other observations of reality into a connected whole. Second, that "sense" in its particular judgments is responsive to rational persuasion based on other observations of reality.

The statement of these two qualifications indicates the general objection to all the manifestations of the position that admits meaning but denies structure. They leave us no basis for evaluating the movements of the human heart. Adherents of this position have the poetic insight that saves them from the error of the more doctrinaire proponents of sociological jurisprudence, who suppose that a man will bare his heart in an interview, but they still fall into the basic error of finding within the framework of the human personality irreducible data 25 - data not subject to evaluation

23. In The Sense of Injustice (New York University Press, 1949), the example of the man punished by an operation that causes him to bark like a dog instead of speaking is the most clearly symbolic. Cahn's treatment of the problem of race segregation in Jurisprudence, 30 New York University Law Review 150, 157-9 (1955) also seems to be particularly explicit in its reliance on symbolic considerations.

24. The treatment in The SENSE of INJUStice of the example of the three men given different punishments for the same offense seems especially to bear this out.

25. These data are not, as they are for the adherent of the nominalist position first discussed, desires that events take place. Cf. note 12 supra. The symbolic insights here described carry the process of reduction one step further: "A desires that $Y$ event take place 
by any extrinsic criterion. Those of us whose experience of life shows that there is a struggle between good and evil for the mastery of a man will not accept such a view.

The position under consideration cannot form a sufficient basis for the evaluation of symbolic conduct. Its adherents do appear to admit of an evaluation in terms of whether or not such conduct means what the actor intends it to mean (hence the Court of Love, and hence also an important trend in literary criticism); or in terms of the importance of the thing meant-how deeply rooted in the personality it is. But if we are right in discerning in the personality impulses toward both good and evil, these criteria cannot be sufficient evaluations. Such criteria will be met whenever a man's conduct symbolizes himself, whereas a man's conduct ought to symbolize what is good in him.

This introduces a teleological element, which cannot be set forth without recourse to a structural system. We are, then, faced with the necessity of furnishing a criterion for integrating the symbolic and the structural: it is not enough merely to recognize both; we must recognize both at once. The formulation that most readily occurs is to amend the symbolic evaluative principle "a man should symbolize what he is" to read "a man should symbolize what he ought to be." The trouble with this is that it is not a sufficient integration. It leaves us with some symbolic norms ("A should symbolize $\mathrm{X}$ ") and other teleological norms ("A should be $\mathrm{X}$ "), whereas the lesson of experience seems to be that some if not all norms are both ("A should be $\mathbf{P}$ and thereby symbolize Q"). At best the suggested formulation fails to connect being $\mathrm{X}$ with symbolizing $\mathrm{X}$ in such a way as to preclude the possibility of a clash between structure and meaning: "A symbolizes $\mathrm{X}$ by $\mathrm{Y}$ and is $\mathrm{X}$ by not-Y." A further objection to the suggested formulation is that it does not have any very plausible connection either with the view that events have real meanings, or with the view that reality has a real structure; it would be a new postulate, and one with little experiential basis.

A better solution may be discovered from treating both man (the individual) and man (the universal) as meaningful events-which the principle that events have real meanings, together with the structural principle that universals are real events, should entitle us to do. The universal bears to

because he regards $\mathbf{Y}$ event as symbolic of $\mathrm{Z}$, an element in A's personality." The desire that $Y$ event take place can thus be evaluated in accordance with the proffered explanation: "Y event is not symbolic of $Z$; therefore A ought not to desire that $Y$ event take place." Now what cannot be evaluated is $Z$. Note that this does not preclude a given critic from finding $\mathbf{Z}$ personally repellent. 
the individual a relation which the structural metaphysicians express by saying that the universal is the "formal cause" of the individual. If there is also a relation between the meaning of the universal and that of the individual, and if that relation can be expressed in teleological terms, we will have the desired connection between teleology and meaning.

Theology discerns just such a relation. Man (the universal), it says, is in the image of God. The individual man, therefore, is teleologically oriented toward the image of God; he ought to be in the image of God. Marriage (the universal) is symbolic of the relation between Christ and the Church. The individual marriage ought, therefore, to be itself symbolic of that relation, although some marriages are not.

It will be noted that in each of these cases we say that the individual ought to mean, but that the universal does mean. The general principle induced from these examples would, then, be that a thing (or a man) is teleologically directed to mean what its formal cause means. ${ }^{26}$ The principle seems to be borne out on the natural level when we say approvingly of a man that he is manly, ${ }^{27}$ observing in a poetic insight that the creature before us carries with it the symbolic value of its class.

It will be noted that the principle just stated does not intrinsically admit of a clash between structure and meaning, since it states a single teleology rather than a relation between two teleologies. It remains to consider whether an extrinsic statement of a different and inconsistent teleology is possible within the limits set by traditional structural metaphysics. This would be possible only if A ought to be something that means the antithesis of what A's formal cause means. But a thing cannot mean the antithesis of what its formal cause means without being the antithesis of what its formal cause is. The formal cause of a thing is by definition what that thing is. Therefore, a thing cannot be the antithesis of its formal cause, or have being such for its end. Structural philosophy, therefore, cannot admit of a teleological statement that clashes with the symbolic teleological proposition stated above. The result of the foregoing reasoning would seem to be that the symbolism of events has a structure, and the structure of events has a meaning. Furthermore, it would seem that all morally objectionable conduct is symbolically objectionable, and vice versa. ${ }^{28}$

26. This is offered, it will be noted, as a criterion for the evaluation of symbols. This makes it a necessary but not necessarily a sufficient standard for evaluating conduct. It is not suggested that all morality can be reduced to this principle.

27. This was a favorite theme of Chesterton's. WARD, Gilbert Keith Chesterton 108-9 (New York, Sheed \& Ward, 1943.)

28. Whether "symbolically objectionable" can be equated with "esthetically objectionable" is a difficult question. It seems likely that the view of art as expression taken in this essay 
We live in a time when the conflict between structure and meaning is being more and more sharply posed by the waning of the intellectual position that denies both. The conflict is one that tears a man in two. It will not do to take sides; to be whole men, we must affirm both structure and meaning, and affirm them in such a way that there is no possible conflict. A criterion that will enable us to do so has been suggested. It remains to consider its jurisprudential applications. Let us begin and end our discussion with the law in itself, considering on the way certain illustrative applications of it.

1. The nature of law.-Current thinking on the nature of law has tended to raise two major questions. The first is whether law is a teleological statement-i.e., command, description of desired behavior; or a mechanical statement-i.e., description of the response expected of certain public officials under certain circumstances. The second such question is to what end, if any, the mechanism is directed if law is a mechanical statement. Most of the familiar issues about the source and binding force of the law can be subsumed under one or the other of these.

The view that law is a teleological statement seems to be held today chiefly by a group of Catholic natural law theorists, who analogize it to the natural law or the moral law, which are, of course, just that-teleological statements. Certain other schools, now largely defunct, such as Austin's, ${ }^{29}$ seem to have entertained similar views. Today we have become so sophisticated about problems of enforcement that this teleological view of law as command no longer commends itself to most of us.

requires that the question be answered in the affirmative. Be that as it may, the symbolic response and the esthetic response as this writer understands them seem experientially identical. From this it follows that what is immoral cannot be beautiful. An admirer of certain of the great love affairs of literature might object to this proposition. But what beauty is to be discerned in these affairs is not inconsistent with the proposition stated. First, just as what we call evil is not wholly lacking in good, but only privative of a greater good than it achieves, so what we call unesthetic is not wholly lacking in beauty, but only privative of a greater beauty than it achieves. Second, just as we can perceive the goodness of one who engages in conduct he erroneously supposes to be good, so we can perceive the beauty of one who engages in conduct he erroneously supposes to be beautiful. Finally, the fact that $A$ supposes $X$ to be beautiful (or good) is an event, and an event other than $X$. This event can be beautiful even though $X$ is not.

29. This does not seem to be inherent in Austin's system, however. The "sovereign" can address himself to his subordinate officials as easily as he can address himself to his subjects. The bias for viewing law as "command" seems to have gone with the times rather than the school. 
The modern schools, therefore, tend to see law mechanically, as occupying a kind of middle ground between ethics and sociology. Concerning themselves peripherally both with how people ought to behave and with how people can be induced to behave, they make it their main task to evaluate law according to its efficacy in obtaining desired behavior. Their doctrine seems to be at least as inadequate as the teleological theory. Empirically, it does not correspond to what people expect of their legal system; ethically, it does not necessarily correspond to what they should expect of their legal system. Many jurists say unenforceable laws are foolish or produce undesirable results, but no one can show either that people do not want them or that they are intrinsically evil.

Prohibition is a good example. We point to it as a horrible instance of the evils of unenforceable legislation, but the person who really believes drink to be a moral evil remains unconvinced. The groups that believe in total abstinence as a moral principle tend still to be prohibitionist in their politics, and tend to regard the politically wet as equivalent to the personally bibulous, rather than as sustaining a different jurisprudential outlook. The proposal made from time to time in Massachusetts to repeal the legislation prohibiting the dissemination of contraceptives gives rise to rather similar attitudes.

The persistent tendency of people to look at law in this way is a fact that cannot be ignored, nor can it be corrected by pointing out the failure of the legislation sought to inhibit the proscribed behavior. The great mass of the people must be seeing in law something that cannot be measured by its efficacy. At the same time, the mechanical insights of current jurisprudence are extremely useful, and should be taken into account in any evaluative consideration of the nature of law. How can the two views, the one popular, the other professional, be reconciled?

The answer seems to be that law is capable of being either a teleological statement or a mechanical statement because esseritially it is neither, but a symbolic statement. It is possible to symbolize the commitment of a society to a certain goal either by stating with solemnity that it is a goal or by establishing a mechanism to attain it. Mechanism is perhaps more important than teleological statement, although societies have been powerfully affected by legal commitments embodied in fictitious mechanisms or in no mechanisms at all.30 There is, then, an important place for the modern schools

30. It was, for instance, largely through formalities and fictions that the Christian commitment to a distinction between temporal and spiritual authority worked itself out during the Middle Ages. It was not until this commitment had been a familiar one for centuries that jurisprudential insight was brought to bear on the problem of expressing it in really effective mechanisms. 
of jurisprudence, and our basic commitments are better expressed because of their efforts to develop effective mechanisms. At the same time, it would be extremely doctrinaire to say that symbolisms that do not include effective mechanism are worthless. Actions speak louder than words; but words also speak, and sometimes with eloquence.

2. Law and the meaning of sacial events: love and marriage.-Let us consider, as an example of the response of law to the meanings of social events, the symbolism of human love and the role of law in carrying out that symbolism.

Human beings are in need of one another. At the same time, with a beautiful concomitance, they are capable of filling one another's needs. This is a structural observation. The corresponding symbolic observation is this: There is a movement in the human heart we call love, which turns itself toward all reality, agonized for expression. Of that agony is born a perception which shows us creatures needful and connatural, whose needs we can supply. A love that is directed toward the whole of reality is thus symbolized in a love that is directed toward another human being, which love, in turn, is symbolized in the act of supplying the needs of that other. This process, considered as a totality, would seem to be symbolic of God's love. ${ }^{31}$

That lovers have special places, special people, special songs, and even special tasks, and are continually creating such things as symbols of their love is a commonplace even among song writers. The sentiments commonly attached to the old homestead, the ivy-covered halls, or a favorite saloon argue that the phenomenon is not confined to love between man and woman, but is connected with love in its broadest sense. Every love, it seems, is creative of symbolism, is symbolized in another love. ${ }^{32}$. The necessary conditions for love, then, are not lover and beloved alone, but lover, beloved, and symbol, a triad. This would indicate that love in the natural order exhibits a principle of "trinity," reflecting the principle of Trinity inherent in the Creator.

Society is the milieu in which this symbolism is accomplished, and, at the same time, it has a symbolic role of its own. Law, which has society

31. This is to say that events have real meanings; the universe is an event: therefore the universe has a real meaning. This real meaning we call God, who is Ultimate Meaning, Himself meaning nothing. This is analogous to the traditional argument from design. Then, by applying to the universe our capacity for symbolic perception, we can learn something about God. The statement in text is that this is what we learn.

32. Dante, In ferno $V$, in the punishment of Paolo and Francesca, seems to suggest that love, when it fails in this regard, destroys itself. Paolo and Francesca, having cut themselves off from the totality of reality by the disorder of their love, are condemned to drift in space in each other's arms without ever touching anything but each other. 
for its efficient cause, ${ }^{33}$. has not only a symbolic role of its own, but also an important function in reinforcing the symbolism of other events in society. Let us consider this function in connection with the symbolism that attaches to the particular form of love that obtains between man and woman.

If the meaning of social relations generally is God's love, the meaning of sex is God's love incarnate, incarnate first in nature, and later in His Son. ${ }^{34}$ Since a thing ought to mean what its formal cause means, it follows that the particular use of sex should be so undertaken as to be symbolic of this incarnate love. Marriage is the name we give the undertaking so to use sex. ${ }^{35}$ Thus, the Church teaches that sacramental marriage is symbolic of the union between Christ and His Church. Similarly, the natural union which sacramental marriage perfects is symbolic of the relation between God and man as it existed before the Incarnation, which relation was perfected in the union between Christ and the Church.

The cruel dichotomy between law and love in the area of relations between man and woman is perhaps the greatest tragedy of Western Christendom. It seems to be no more than a bitter accident of history that the courtly lovers, who perceived the necessity for surrounding the love between the sexes with a set of almost liturgical symbolic observances in order to connect it properly with the mystery of life, treated love itself as an irreducible datum, while the philosophers and theologians, who perceived the place of love in a whole reality, confined themselves to merely

33. "Law," as used in this essay, means human law. To use "law" univocally of human law and "divine law," "natural law" or "moral law" requires complete acceptance of the view that human law is a teleological statement or command-a view which this writer rejects. See pp. 104-6, supra.

34. It is not intended that incarnation should be understood univocally in reference to the creation of nature through the Word and the Incarnation of the same Word in Jesus Christ. The difference is similar to that between sacramentality as found in nature and sacramentality as found in the sacraments of the Church. In each of these cases we have something not otherwise sensible made so through a symbol, but in the two examples from revealed theology we go beyond that to a union between the symbol and the thing symbolized, which transcends philosophy entirely, and which even theology labels as a mystery. Christ, like all men, like all nature, symbolizes God; but of all the symbols of God, only Christ is God. Similarly, the Bread which symbolizes the Body of Christ is what it symbolizes.

35. A relation in which the use of sex is to be subjected to some principle of exclusiveness and some principle of endurance, either complete or partial, seems to be ipso facto a marriage as anthropologists use the term; where the principles of exclusiveness and endurance are the ones to which the use of sex ought to be subjected, the relation is also a marriage as moralists use the term. It should be noted that for this reason the universal "marriage" cannot properly be regarded as having a meaning independent of that of the universal "sex." The meaning of sex is the creative love of God, and the meaning of marriage is that same love considered as having certain attributes-fidelity, endurance, and the likewhich it in fact has. 
teleological observations. As has already been pointed out, the inconsistency between these two insights is spurious. God's love is trinitarian, and therefore expands itself in the multiplication of created symbols. The symbol of its incarnation must touch all nature, as the courtly lovers made it do. At the same time, God's is an enduring creativity, the product of an enduring love; it cannot be symbolized in any transitory thing.

It was inevitable, therefore, that the symbolism of courtly love should eventually be absorbed into the marriage relation. ${ }^{36}$ It is almost by definition that the enduring quality of love must be expressed in marriage. Under the form of marriage sex and its symbolism become expressive of the emanation of the fecundity of nature from the everlasting love of God. ${ }^{37}$ In mankind there is at least a dim awareness of the rightness of the connection between love and marriage-an awareness, fortunately, which neither poet nor philosopher has been able to efface.

The law has had a checkered career in its relation to this complex of symbolism. The structural philosophies of law did nothing to strengthen the tie between love and marriage except at times to bring about attempts to punish fornication and adultery as violative of teleological principles. Their failure to attack the commercialization that robbed marriage of its symbolic character through much of Western history must stand to their particular discredit. ${ }^{38}$ Meanwhile the importation of the symbolism of courtly love into marriage has led to a tendency to bring in also the instability of the courtly lovers. The law, under the aegis of nominalist philosophy, has generally reflected this trend. The ready availability of divorce in our society is a matter of comment for persons of all shades of opinion.

The symbolic considerations just discussed should indicate that the controversy over whether divorce legislation is too "lax" misses the point. The symbolism of sex, rightly understood, calls for an integration of that faculty into an indissoluble union where, in turn, further forms of symbolic behavior

36. This process is discussed in C. S. Lewis, The Allegory of Love, passim (Oxford, 1936).

37. For the believer in traditional forms of Christianity, marriage offers the further symbolism of the gradual revelation with which God's love became known, the dedication that made the Old Covenant, the immolation that made the New, and the perpetual reaffirmation of something once done which characterizes the life of the Church in time.

38. It is not suggested that law could have eliminated this abuse, at least without completely altering the framework of society, but it could have taken important steps in that direction. Civil law could, for instance, have eliminated the right of a guardian to profit from the marriage of his ward, or at least the right to exact a forfeit from a ward who refused a tendered marriage. It could have gone further and required parent or guardian to account to the married child for any money or property received on account of the marriage. Ecclesiastical law could have extended its prohibitions against simony to apply to any tampering with marriage in the interest of profit. 
take place. Those who favor divorce legislation argue, in effect, that a marriage that is not "fulfilling its function" (i.e., not having love expressed in it) should be eliminated from society. The structural arguments current among opponents of divorce deny this argument but do not refute it. The real refutation of the argument for divorce does not lie in a consideration of the pathology of marriage at all, but in the element of indissolubility which, as has been shown, is essential to the symbolism of sex, and therefore essential to the proper achievement of the goal of any marriage. The zeal for the elimination of the pathological marriage is misplaced not because there is a social purpose in retaining the pathological marriage as such, but because the introduction of divorce as a principle deprives all the lovers in the world of the opportunity to express the true meaning of their love by giving themselves to one another irrevocably.

To be sure, the existence of divorce legislation does not prevent individual couples from perceiving the true meaning of their love and resolving to govern themselves accordingly. Better, they may embrace a system of moral or religious dictates that will connect up their symbolic perceptions to the rest of reality and hold their mutable nature to the immutable gift they have undertaken. But if society is a milieu for the expression of the symbolism present in human love, those who undertake the relation which, it has beeen suggested, is the manifestation in their bodies of the eternal incarnation of divine love are entitled to have the symbolism of that relation taken up by society. What is indissoluble by the twin teleologies of structure and meaning ${ }^{39}$ should be indissoluble by the standards of society. Otherwise, love, the meaning of the relationships sustained in society, is sundered from incarnate love, the meaning of sex. The connection must be maintained by the symbolism of law both to sustain the lovers in the achievement of their purpose, and to permit society to be enriched by their love.

In maintaining this connection, the law has two functions. The first is to symbolize society's approval of behavior conformable to the symbolism of sex, ${ }^{40}$ thereby strengthening the will of the individual so to behave. This

39. The particular marriage should be indissoluble by virtue of the principle that it should mean what its formal cause means. See note 35 supra.

40. A recent report of a commission appointed by the Supreme Court of New Jersey to study problems of marriage is instructive in this regard. One of the most important of the recommendations of this commission was that the form of civil marriage be amended in order to provide the occasion with greater solemnity and make it more symbolic of the importance of the step being taken.

Similar considerations may point to an aspect of the law of obscenity overlooked in the teleological approach that reached its ne plus ultra in Judge Frank's opinion in United States v. Roth, 237 F.2d 796, 801 (2nd Cir. 1956). This kind of legislation should be classified not with that against sedition but with that against spitting on the Flag, e.g., Uni- 
approval strengthens the specialized love in the marriage relationship by supplying an additional connective with the generalized love of neighbor in society, and hence with all reality, in keeping with the principle of trinity discussed above.

The second function of law in this area fills a more basic need, but fortunately a need that can be supplied by forces other than law. That is the need for externalizing the binding force of the commitment which, as we have seen, the love between man and woman requires to achieve its meaning. What the symbolism calls for is a gift of self. But human nature being what it is, a human being, however much he wants to, cannot make a gift of himself in any final way. Whatever his present resolutions, his will is free and he can change them. It is only when some external power will hold him to his present resolution that he can give himself at all, and then only in a symbolic way. Without sanctions, a human being cannot give, and without giving he cannot love. The elimination of the necessary sanctions, then, cheats him seriously. These sanctions are provided for some of us by principles of religion or morality, but a properly functioning society would strengthen these sanctions by law so that the gift would be of social as well as philosophical or theological significance. ${ }^{41}$

3. Law and the meaning of society: kingship and government.-Turning from the response of law to the meaning of social events, let us consider the response of law to the meaning of society as a whole. It has been suggested that society is the milieu for certain social events, and that the ultimate meaning of these events is love. The process of generalizing the meaning of these social events into an underlying meaning is that of generalizing particular loves into an underlying love, which is God's love. As that love is an emanation of God, so the social event is an emanation of society. This would indicate that society in the abstract is a symbol of God. A particular society ought, therefore, in its relationships with its members, to symbolize God in His relations with mankind.

Theologians call this relation the fatherhood of God, on account of the other great social relationship that symbolizes it. Carrying through the symbolism, the response of humanity to the fatherhood of God-turning upon the neighbor by virtue of the principle of trinity-is called the brotherhood of man. The doctrine that these two principles should be symbolized

form Flag Act §3, 9A U.L.A. Obscenity is not, in other words, chiefly conduct inciting to objectionable conduct; rather it is symbolic conduct objectionable, if at all, in itself. 41. This would argue that the first reform of divorce legislation should be one making it possible for couples at the time of their marriage, after careful screening to insure the seriousness of their intentions, to waive the availability of the divorce laws. 
respectively in the relation between a society and its members and that between the several members may be called the doctrine of the familiality of society. Applying this doctrine to society as organized for the purpose of sustaining a relation with its members, we may call it the doctrine of the familiality of the state.

The ancient and medieval institution of kingship seems to have symbolized just such a doctrine. The King was expected to behave as a father to his people, and, indeed, was often called such. ${ }^{42}$ Among ancient peoples, outside the Judeo-Christian tradition that began with the inauguration of the levitical priesthood through divine revelation, the King-head of the state-seems to have shared with or inherited from the patriarch-head of the family-the function of priest, or symbolizer of God before man and man before God. Even in Christian states, the King was set apart by a religious anointing that constituted one of the holiest rites of the Church excepting the seven sacraments.

The downfall of monarchy as an institution was inevitable with the split between structure and meaning. On the one hand, those who emphasized structure subjected the institution to a searching teleological examination that it was obviously ill-equipped to stand;43 on the other hand, exponents of the institution concerned themselves with symbolic formalities and neglected to connect themselves with reality by acting for the good of their subjects in accordance with the fatherhood they were intended to symbolize. ${ }^{44}$

But over and above these objections, there must stand a further objection to monarchy as it was conceived of in the Middle Ages - one which an integration of structure and meaning will not answer. This objection is that it symbolized the dignity of fatherhood without adequately symbolizing the dignity of sonship. The symbols we of the Western democracies have substituted for those of monarchy have been those of the dignity of the citizen. ${ }^{45}$

42. Our term "parens patriae" seems to be a survival of this conception.

43. The present condition of England should indicate how completely the institution of monarchy depends on a commitment to the principle that man does not live by bread alone, and at the same time how complete a compartmentalization between bread and non-bread has been thought necessary to the maintenance of such a commitment in the modern world. 44. For an example of the same thing at work on the domestic level, consider how the symbolism of a man's bringing his wife flowers is vitiated if he beats her or goes out with other women. A life or an institution must be integral if it is to be meaningful.

45. It must be pointed out again that a functioning legal institution producing a real effect is a symbol of the sentiments entertained by its authors, or of the considerations productive of that sentiment. Thus, the establishment of provisions in our Constitution securing certain rights to the citizens, together with the judicial machinery for making these rights good, is symbolic of our commitment to the dignity of the individual, or those provisions and that machinery are symbolic of that dignity itself. Structurally, dignity and civil rights are incommensurable; rights flow from dignity neither as an effect from its cause nor as a conclusion from its premises. If, as this writer must insist on experiential grounds, a senti- 
The first impetus of individualism, which denied the brotherhood of man, has passed, but the heritage of that movement in symbols of individual dignity has been found valuable and has endured. To retain these symbols and yet add to them some of the symbols of familiality that passed with the monarchy, is the difficult task that confronts the modern state. Modern social legislation has made a beginning in this direction.

4. The meaning of legal events: crime and punishment.-The considerations advanced thus far should indicate the way to go about evaluating particular provisions of law. Let us take the criminal law as an example. Society, being symbolic of certain aspects of God, can powerfully symbolize in its legal structure the concurrence between civic righteousness and the Divine Will, showing how the citizen may find his underlying connectives with reality. Society, therefore, should attempt in its laws to erect a symbolism of its commitment to justice. That commitment is best symbolized by working for justice with all the tools at society's command-not because the achievement is more important than the commitment, but because the commitment is vitiated if any tool is knowingly overlooked.

The application of this principle is most forcefully exemplified in the various aspects of the criminal law. Treatment of the unjust affords society its most readily available means for symbolizing its approval of the just, vindicating his way of life, and, in some cases, his person. Let us see how this can be used as an evaluative principle.

Prohibition has already been offered as an example of an unenforceable law enacted in response to a moral conviction entertained by its proponents. Some commentators suggest laws against prostitution as another. Yet the impetus for Prohibition has largely died out, while the laws against prostitution continue on the books. It can, of course, be argued with a good deal of force that the moral sentiment opposed to drinking does not command the same public acceptance as that opposed to prostitution. It can also be argued that the law is more effective at inhibiting prostitution than it was at inhibiting drinking. It seems, though, that neither of these points is conclusive. What seems more important than either, although causally connected with both, is that the laws against prostitution are almost universally regarded as a commitment on the part of society to the moral principle that opposes the practice, whereas the prohibition laws were not only disregarded, but disregarded in such a way that few were able to

ment, such as appreciation of human dignity, is not identical with the desire that an event take place (see pp. 93-4, supra), there can be no logically necessary connective between such a sentiment and the bringing about of an event. The experiential connective of symbol supplies the defect. 
consider them expressive of a commitment to the moral principles of total abstinence.

The principle for the evaluation of criminal laws, then, should be a consideration not of whether they effectively inhibit the proscribed conduct, but of whether they effectively express a commitment on the part of society to a principle that opposes such conduct. Adherents of such a principle, if they can achieve legal expression to this extent will probably find the law an ally in commending their moral position to the public, and will find their way of life most effectively served by regarding society as congenial. If not, they will probably find their way of life better served by abandoning all attempt at legal expression and by regarding the particular society as hostile.46

Turning to the realm of criminal procedure, we find that the approach that regards law as a mechanism has again been inadequate. It has led many to question whether some reform of the various steps calculated to protect the innocent would not avail to convict more of the guilty without any undue burden on the innocent; indeed, some have gone so far as to question whether it really is preferable to let the guilty go free rather than to convict the innocent. A certain amount of light can be shed on these problems by the symbolist approach, evaluating law in terms of its function of expressing the devotion of society to the principles of justice, and therefore to the cause of the just man. In the criminal courts as nowhere else the drama of the struggle between good and evil is played out. The accused is a monumental figure in this drama, to be dealt with in a monumental way.

The whole majesty of society is balanced finely on a point, and that point is the individual. The processes of justice must be likened to the power of God, who created the vastness of the skies and yet regards the fall of a sparrow. That no consideration is too trivial to be scrupulously weighed in the fine balances of justice is precisely the assurance the individual craves in the midst of the immense forces that are at work around him. And in this process, the punishment of the guilty is not an end in itself, but is symbolic of the high regard we have for the innocent. Therefore, it is vital to the success of the drama to insure that the victim be not himself innocent.

46. This is the nature of the issue confronting, for instance, the Church of England. Those who favor retaining the Establishment argue that abandoning it would be an admission that England is no longer Christian. Those who favor disestablishment argue that England is in fact no longer Christian, and the Church by retaining an official status impairs its own witness for Christianity. The problems of American Catholicism, although not as acute as those posed by Establishment, are in a way similar. The more prominent Catholic writers feel that by emphasizing the way in which American society is Christian they can win for Catholicism a more highly respected place in that society. Others feel that by emphasizing the way in which American society is secularistic they can eventually win it, or at least some of its members, over to a fuller practice of Christian principles. 
If we seem to exaggerate our regard for this point, it is for good reason.

This same drama of the struggle between good and evil has more effect than we realize on our approach to punishment. Generally speaking, we have two kinds of punishment: capital punishment and imprisonment. In the case of capital punishment, having erected the malefactor by our judicial process into a symbol of the evil principle in the body politic, we destroy him in token of the moral rebirth of the state through the elimination of the wrong done. The Church provided us with prison as a means of punishment, thus adding to the symbolism of justice that of mercy, which capital punishment lacks. In the drama we are working out, prison plays Purgatory where the gibbet plays Hell. From this place of suffering, the criminal can emerge purged and purified, and so be a fit subject of mercy.

But here as in so many other areas, the denial of real meanings in events has subjected the legal institution to a teleological analysis it is unable to stand. We have seen posited as the purpose of punishment any of the following: to affect the decision of those deciding whether to commit crimes or not, by putting them in fear of punishment; to deprive the criminal of the opportunity to repeat his crime; to rehabilitate the criminal by exposing him to certain wholesome influences which he will be unable to escape because of his confinement.

The application of the first or the second of these theories would make nonsense of our penal system. For instance, to get the maximum fear reaction from potential criminals, we would have to disseminate more widely the horrors of punishment. We would have to make hangings public again; and revive the stocks. On the other hand, if our purpose were to deprive the criminal of the opportunity to repeat his crime, the stocks would not do at all, nor would any but the longest jail sentences. Death, or exile, would be our chief punishment. But embezzlers, who are law-abiding in other respects, would not have to be punished at all. Listing them with the bonding companies would take care of them. Both of these theories are obviously post hoc, invented to explain a system already in operation. Neither explains it adequately, and no one has attempted systematically to apply either to the reform of existing arrangements.

Let us turn our attention, then, to the third theory stated above, the one that is actually influencing penology-that of rehabilitation. The problems of structure and meaning in the sciences that undertake the task of rehabilitation set by that theory are numerous and complex; it would be presumptuous to attempt to resolve them here. Suffice it to say that these sciences operate by symbols, and their symbols run counter to the symbolism suggested above for the criminal law. The idea seems to be that criminal 
behavior stems from a "self-image" of the criminal as sustaining an antisocial role, which he must symbolize in antisocial acts. It then becomes the business of the rehabilitator to engage in symbolic behavior calculated to impress the criminal with a new image of himself as sustaining a socially acceptable role. ${ }^{47}$

This, of course, runs counter to the symbolic conception discussed above whereby the criminal process symbolizes the eradication of the evil principle from the midst of the body politic, with the criminal serving to symbolize the evil principle. The rehabilitators have accordingly attacked the symbolism of the criminal proceeding, and have succeeded in weakening it in a number of ways. The solution of the problem raised by this attack would seem to lie in the concept of purgation. By a symbolic purgation, the criminal can be freed from his symbolic status as a representative of the evil principle, and can become a fit subject of mercy, a fit subject of rehabilitation. The development of symbols that will adequately embody this concept without sacrificing the rehabilitative function is a task that should engage the attention of both psychologists and lawyers.

5. The meaning of law.-It has been noted in passing that what most scholastics call natural law is a body of teleological observations, and that human law is something else. Human law is responsive to the human condition, whereas this kind of natural law is inherent in it. Human law, being the product of behavior, is an event, and therefore can have meaning. This natural law, being only a teleological statement, is not an event, and therefore cannot have meaning. That there is such a natural law, or rather, that there exist creatures sustaining the teleology described as the natural law, is an event and a meaningful one, but the natural law itself is not.

The person who denies that events have real meaning is apt to look at law either as stating a teleology or as stating a mechanism to attain it. The person who denies that reality has a real structure is apt to reject law altogether or to reduce its function in some way, since he sees law as inimical to some meaningful conduct that he favors. These can be called respectively

47. None of the three theories just considered explains adequately the defense of insanity in criminal proceedings. The Man Undeterred by the Fear of Punishment constructed by the followers of the deterrent theory may exist, but has nothing to do with the man the law exonerates as insane. Under the prevention theory, physical restraint would be as much of a preventative for the insane as for the sane. As for the rehabilitators, it is, of course, quite possible that the rehabilitation of the insane presents wholly different problems, and calls for wholly different techniques, from that of the sane. But an administrative decision within the penal system would be a far better way of recognizing this difference than would a court determination. The real reason for exonerating the insane man is that he lacks the moral guilt necessary to make him a fit actor in the drama that the law enacts over his crime. 
the teleologist and the sentimentalist. We have seen them at work throughout this essay. What both seem to be missing is a factor inherent in teleology - the incidence of failure to achieve. This factor, as present in the human condition, we call pain.

We are creatures teleologically directed toward the expression of love in society through the symbolism of producing in society a perfect concomitance of ministry and need. It has been suggested that the love so to be expressed is that of God for our neighbors. Since the direction is teleological it is not inevitable. Our actual conduct often symbolizes to a greater or less extent not love but its antithesis. When this happens, the inarticulate longing of the human creature for love is turned in upon itself; the social context becomes productive of pain.

Love-our turning toward one needful and connatural-takes a different form in response to pain. We call it compassion, or pity-our turning toward one connatural and suffering. This pity is itself a pain, and carries with it a special symbolism. God Himself came down and set His seal on it. In our wounded world, it is the touchstone of love.

It is in this pity that the sentimentalist and the teleologist alike fail. The teleologist is indifferent to pain, because he has an end to achieve. Being philosophically persuaded that the achievement of that end is a good, he is willing to put up with the incidental evil-pain-that he finds empirically to result from the achievement. We say of him that he is pitiless. The sentimentalist, on the other hand, does experience pity. His difficulty is that he is unwilling to experience it. His humanitarian efforts are directed not at expressing the pity he entertains toward the suffering, but at eliminating the source of it in order that this painful emotion may trouble him no more. ${ }^{48}$ The result is that he is desperate to alleviate the suffering that plays on his emotions at the moment, regardless of the cost in suffering that does not affect him emotionally.

Neither the struggle of the teleologist to improve the lot of an abstract humanity nor that of the sentimentalist to eliminate pain from his immediate environment is an adequate response to human suffering. The only adequate response is pity, which extends to the sufferer its special symbolism of love reconstructed through pain. If we have not yet learned this from the

48. Caryll Houselander in Guilt (New York, Sheed \& Ward, 1951) synthesizes a great many of the aberrancies possible to the human psyche in terms rather like these. But what is here called desire not to feel pity is there called desire not to feel guilt. It seems likely that the two terms refer to the same thing. Pity either stems from or carries with it a certain sense of responsibility for the misfortunes of others that might well be characterized as guilt. The feeling, considered as the source of psychological abnormalities brought on by the attempt to escape it, is usually referred to as guilt. 
theologians or the poets, or from our own experience, it seems likely that we will soon be learning it from the psychiatrists. But what we are dealing with here is law, the most solemn expression of a society qua society. The task is to make this expression into one expressive of the pity and the dignity that inhere in the human condition.

It is with man as sufferer that the law must chiefly deal. Law symbolizes, to be sure, all a society aspires to, but it is in its dealings with suffering that the aspiration is shown forth. It is not by accident that it was those who suffered least who coined the maxim that that government is best which governs least. The jurisprudence of nineteenth-century individualism seems to have concerned itself almost exclusively with the situation of those who did not suffer; it is for this very reason that we now consider it unsatisfactory.

The function of human law in dealing with the sufferer points up again the difference between human law and natural law (the term again being used as most scholastics use it). Natural law deals with the end of man, which is happiness, whereas human law deals with sin and suffering, privations of the end of man. The natural law says "thou shalt not kill." The human law begins where the natural law leaves off, with the matrix in which the slayer, the slain, and the bereaved present their conflicting claims and their common witness to the condition of mankind. It remains for the law to touch the scene with a human pity that shows forth in some way the compassion of God.

We can show pity for the sufferer in striving to alleviate his lot; in striving to share it; or, as will be seen below, in avenging him. The second of these alternatives has always been regarded by Christianity as the noblest, since it was the one especially chosen by Christ Himself. It seems, however, to be one the law can only minimally pursue. Only a human being can suffer, and the decline of personal government has been making it more and more difficult for the law to suffer in the person of a human being. Also, the law is inherently powerful, and some symbolism of impotence is almost inescapable in suffering. Only in time of war or civil disturbance when law becomes in fact powerless can it effectively share the suffering of the citizen, and thereby express pity for him. ${ }^{49}$ Vengeance, the third of the alternatives stated above, is the earliest form of legal expression of pity, and still an important one. This form was probably once regarded as the one most appropriate to law because it is one that only law can utilize to advantage. Vengeance at its best is a symbolic act whereby the dignity

49. Thus, it is said that the last of the Byzantine emperors, when the city was about to fall to the Turks, went about the walls asking the citizens to forgive him if he had offended them in any way. 
of a man is asserted by the symbolic degradation of one who has denied it. As has been indicated in the above discussion of the criminal law, the success of the gesture depends on the development of a symbolism that asserts the dignity of the person wronged without denying that of the wrongdoer. This, in turn, depends on abstracting the wrongdoer as such from his individuality, and degrading in his person not himself as an individual, but the evil principle he is made to symbolize. This private vengeance can never accomplish. Thus it is that vengeance seems everywhere to be the first function attached to the legal system and the first function reserved to it.

But the alleviation of suffering, although a relatively recent notion in jurisprudence, seems to our generation the most natural expression of pity for the law to engage in. This is as it should be. No expression of pity is adequate if we at the same time withhold from the sufferer relief it is in our power to give. Our advances in the understanding of the effective use of legal devices for the accomplishment of social results make it imperative that we address ourselves more and more to the relief of suffering. The question, mooted sometimes in this as in other contexts, of whether we would be happier if we did not know so much cannot affect the use to which we put the knowledge we have.

At the same time, we must approach this alleviation of suffering with a sense of the significance of what we are doing. We have seen here the sustaining role of law in the great and not always successful travail of humanity to impose on brute matter symbols of the love that called it into being. From society, just as from the individual, when that travail is denied overt recognition, come monstrous unconscious and misshapen symbols, which no amount of material prosperity will inhibit. ${ }^{50}$

The need for law, then, is a need not for material well-being, but for symbols of sustenance, symbols of pity. Material reform may be the symbol required, but it is as symbol, not as reform, that it will be judged. The difference between the reformer who pities and the reformer who does not is a subtle one, but it does not escape observation, especially by the beneficiary of the reform. No kind of legal institution will be of service to humanity unless it carries on its face the mark of being established in love. A society, however well planned, will be a failure if history records of its members that they did not love one another. Without love, law is a shell; but love can make it a vessel into which can be poured the brotherhood of the whole suffering world.

50. As to the individual, this is the thesis of Houselander, op. cit. supra, note 48 . The work does not touch on society as such, but the discussion of the case of Irma Griese would seem to indicate that the conclusions have societal applicability. 